\title{
What are we saving? Tracing governing knowledge and truth discourse in global COVID-19 policy responses
}

\author{
Lynette Shultz ${ }^{1}$ (1) Melody Viczko ${ }^{2}$
}

Published online: 18 May 2021

() UNESCO Institute for Lifelong Learning and Springer Nature B.V. 2021

\begin{abstract}
As the world went suddenly into lockdown due to the COVID-19 pandemic, sending individuals to their homes and shutting businesses and institutions, the closing of schools posed big problems. The majority of the world's children were out of school, leading to the longest sustained period of school closures in history. We saw educators turning towards responses not aimed at collegial and community-engaged strategies for education in an emergency but at online learning cast as education/ business as usual. This study explores the logic driving this global response through analyses of the documents released by three key global education actors: (1) the OECD and its paper A Framework to Guide Education Response to the COVID19 Pandemic of 2020; (2) UNESCO's Global Education Coalition \#LearningNeverStops; and (3) the World Bank's Guidance Note on Education Systems' Response to COVID-19; and Guidance Note: Remote Learning and COVID-19. The authors of this article draw on Carol Bacchi's approach to poststructural policy analysis to make visible the key concepts and binaries used within policy texts and to understand the "technologies of saving" that were invoked in each policy response, locating the education programmes, activities and actors within knowledge practices in educational reform. This article explores the World Bank, OECD and UNESCO responses using an analysis of knowledge harmonisation and difference among these institutions as well as their location as key norm-setters and governing actors in the field of education. The authors argue that all three responses privilege private-sector providers of digital technology. The consequence of these responses is that technologies of saving have centred on privatised, corporate edu-business and edu-tech aimed at online education delivery, bringing significant risks for the erasure of local knowledges. The authors' study suggests that local policymakers, including community-based and national actors, must be invited into the discussion to envision other possibilities and to name the potential destructiveness embedded in the international organisations' actions.
\end{abstract}

Keywords poststructural policy analysis $\cdot$ global policy actors $\cdot$ international organisations (IOs) $\cdot$ epistemic injustice $\cdot$ technologies of saving

Extended author information available on the last page of the article 


\section{Résumé}

Que sauvons-nous ? Sur la piste du savoir dominant et du discours de vérité dans les réponses politiques mondiales à la COVID-19 - Quand le monde s'est brusquement confiné à cause de la COVID-19, renvoyant les gens chez eux et fermant entreprises et institutions, la fermeture des écoles a posé de gros problèmes. La majeure partie des enfants dans le monde se sont retrouvés hors des établissements scolaires, ce qui s'est traduit par la plus longue période de fermeture des écoles de toute l'histoire. Nous avons vu des pédagogues se tourner vers des réponses qui ne visaient pas à trouver des stratégies éducatives collégiale et axées sur la communauté dans une situation d'urgence mais à simplement adopter une forme d'apprentissage en ligne pour continuer d'enseigner comme d'habitude. Cette étude se penche sur la logique qui sous-tend cette réponse globale en analysant les documents publiés par trois acteurs clés de l'éducation : (1) Un cadre pour guider une réponse éducative à la Covid-19 en cas de pandémie de 2020 de l'OCDE; (2) la Coalition mondiale pour l'éducation \#ContinuitePedagogique de l'UNESCO et (3) deux notes d'orientation de la Banque mondiale : Note d'orientation sur la riposte des systèmes éducatifs au COVID19 et Note d'orientation mise à jour:Apprentissage à distance et COVID-19. Les auteures de cet article s'inspirent de l'approche analytique de la politique poststructurelle de Carol Bacchi pour mettre en relief les concepts clés et les binaires utilisés dans les textes politiques, et pour comprendre les « technologies de l'économie » invoquées dans toutes les réponses politiques, situant les programmes, les activités et les acteurs de l'éducation dans des pratiques du savoir en réforme éducative. Cet article examine les réponses de la Banque mondiale, de l'OCDE et de l'UNESCO en recourant à une analyse de l'harmonisation du savoir et des différences au sein de ces organismes ainsi que leur position en tant que décideurs clés qui imposent des normes et acteurs déterminants dans le secteur de l'éducation. Les auteures affirment que les trois réponses privilégient les fournisseurs de technologie numérique du secteur privé. En conséquence, les technologies de l'économie se sont focalisées sur un entrepreneuriat et une technologie privatisés en vue de proposer des services éducatifs en ligne, ce qui met considérablement en danger les savoirs locaux risquant ainsi d'être effacés. L'étude des auteures indique que les politiques locaux, y compris les acteurs communautaires et nationaux, doivent être invités à prendre part au débat afin d'envisager d'autres possibilités et dénoncer le pouvoir destructeur potentiel que recèlent les actions des organisations internationales.

\section{Introduction}

In March 2020, schools were closed around the world as nations and communities moved swiftly to control the spread of the COVID-19 virus that had quickly become a global pandemic. ${ }^{1}$ The rapid and extensive movement of the virus across borders meant that policies were made and remade just as fast as

\footnotetext{
${ }^{1}$ Pandemic status was officially declared by the World Health Organization on 11 March 2020 (WHO 2020).
} 
news spread of the imminent danger of a massive loss of life. Schools and higher education institutions were closed immediately, along with other spaces where large groups of people would normally meet and interact. The impact has been unprecedented in its scope. While the world has grown used to schooling being abruptly halted in environmental disasters, wars, political upheavals and other comparatively localised disasters, the COVID-19 pandemic changed the relations and activities of education systems worldwide. The majority of children were out of school, leading to the longest sustained period of school closures in history. We saw educators turning towards responses that cast online learning as education/business as usual. International organisations (IOs) sought to lead responses through privileging relations among digital technologies, education actors, and education businesses (edu-business) to champion online and digital modes of learning as necessary to save during the pandemic.

The study we present in this article explores the logic driving the policy by three key global education actors: (1) the World Bank; (2) the Organisation for Economic Co-operation and Development (OECD); and (3) the United Nations Educational, Scientific and Cultural Organization (UNESCO). These IOs, all major players in the global governance of education, responded quickly to school closures. We explore their responses through an analysis of their location as key norm-setters and governing actors in the field of education and of knowledge harmonisation and difference among these institutions.

These IOs have dedicated decades of work to securing their roles in leading education policy on a global scale. They have mostly been well-funded and, in the case of UNESCO, been given increased visibility by other IOs. In this role, the World Bank, the OECD and UNESCO are known to present solutions to "save" education. In international relations, the contested relationship between saving and destroying has long been a topic of concern. Consider the example of the trope "the necessary war" spread through American media and beyond, quoting officers who declare "it became necessary to destroy the town to save it" (Greer 1968). The justification of invasion was in the act of saving where the destruction of the act was made secondary (see Lind 1999). Declarations of saving should always be examined for their destructive consequences. Our study set out to do this by examining declarations of saving education made in international organisation policy statements during the COVID 19 pandemic and the potential destructive impact embedded in these declarations. Sotiria Grek speaks to the moral urgency communicated by global actors:

Financial investment in collaborations is increasing and so is hope: If only we had known, we could have acted (Grek 2020, p. 309). 
Consequently, IOs are in the business of saving education. But what exactly are they saving? Drawing on poststructural policy analysis, ${ }^{2}$ we set out to examine how the education policy discourses in these three IO responses to COVID-19 constitute the "problem" of education during the pandemic.

This analysis is important and timely, given the complexity of analyses that are needed to understand the disruptive effect of COVID-19 on education and other public policy sectors. Ola El-Taliawi and Kris Hartley provide a good description of the complexity of these disruptions across economic, social and political systems, arguing the pandemic bore

the hallmarks of complex policy problems: multifaceted within and across political domains, elusive of full measurement and prediction, and exposing latent state-society tensions ... and governance capacity limitations (ElTaliawi and Hartley 2020, p. 1).

In education, we saw a uniformity of turning towards private-sector providers of digital technology as the key legitimate response to school closures. A network of IOs and non-governmental actors, as well as edu-business and edu-tech providers across responses have shown there has been a remarkable global consensus on prioritising digitally mediated distance education (Williamson 2020), ensuring the pandemic problems of education lead to economic gains.

We became concerned as we observed a unifying trend that did not include collegial and community-engaged strategies for education in an emergency. These speedy responses from IOs lacked any reference to knowledge created and promoted through the frameworks of, for example, the Sustainable Development Goals (SDGs; UN 2020 [2015]) or the United Nations Declaration of the Rights of Indigenous Peoples (UNDRIP; UN 2007), which provide holistic readings of ongoing crises, emergencies and policy knowledge that speak to creating strengthened and resilient communities. Such glaring omissions in the COVID-19 pandemic responses to issues of sustainability, climate crises and human rights are alarming. From a poststructuralist perspective, we consider the responses we analysed to constitute the problems of education during the pandemic as responses. In examining the policy responses of the World Bank, the OECD and UNESCO to the pandemic crisis, we were interested to know:

- What technologies of saving are used in these IOs' responses to COVID-19 and their directions to educators?

- In what ways does the interplay of these IOs' responses provide a governing influence on education in the global emergency caused by COVID-19?

\footnotetext{
${ }^{2}$ Poststructuralism is not a singular theory. Carol Bacchi's (2009) "What's the problem represented to be?" (WPR) approach to policy analysis is underpinned by poststructuralism to draw attention to the politics by which meaning is given to concepts. One key contribution of poststructuralism is the idea that meaning is pliable, and consequently, political. In this way, poststructural policy analysis involves understanding how we are governed through policy by interrogating the ways in which certain concepts and their meanings in policies function to make some ways of acting and being legitimate and others illegitimate.
} 


\section{Technologies of governance and saving}

The ways in which IOs have exerted influence in distributing policy knowledge into local educational governing practices have been a concern in research since IOs' work emerged in these areas in the 1990s. For example, in the context of examining the unfolding of the International Adult Literacy Survey (IALS), the OECD's first literacy study in the early 1990s, Grek (2020) argues that this format allowed the IO to develop its capacities for comparative testing regimes, as it instigated the persuasive power of the OECD in education policy comparisons, while also increasing revenues for the agencies administering the survey (ibid.). The formalised survey became a means of governing, since it

created a circle of like-minded expert communities, who found in these studies a platform for promoting the problematisation of specific issues, their institutionalisation through their exchanges and the setting up of the study, as well as their legitimation, in the form of advice to failing countries, once the results were published (Grek 2020, p. 14).

These relations work to set the boundaries of the field of education, what is considered legitimate in governance, curriculum, pedagogy, and overall goals of education (see also Ball 2012; Robertson 2012; Bonal and Rambla 2003), thereby changing epistemological values through comparative systems as a form of normative governance (Woodward 2009). The policy knowledges of the IO responses matter in how local education is carried out.

Michel Foucault's concept of governing knowledges (Foucault 1980) draws attention to how society comes to be administered through practices of organising - not through conscious intent, but rather through governmental technologies. Political scientist Carol Bacchi explains that in governmentality theory, "technologies comprise the means by which governing becomes practicable" (Bacchi 2020, p. 90), such as the means by which performance data or evidence-based policies become technologies that govern the way in which education is practised. Coined by Foucault (2009 [1978]), gouvernementalité [governmentality] - a contraction of "gouvernement" and "mentalité" - concerns the techniques and strategies through which society is governed. Importantly, government here does not mean only conventional formal institutions but also "any form of activity that aims to shape, guide or affect the conduct of people" (Bacchi and Goodwin 2016, p. 5). Studying these governing technologies involves examining how power is formed through the relations between knowledges, expertise and subjects. Consequently, the focus on technologies of saving in our article requires addressing the focal two-part question about which instruments are used in policy to save education during the COVID-19 crisis, and which knowledges make them seem reasonable and actionable.

These knowledges matter in our study for (at least) two reasons. Following Foucault (1980), we recognise that knowledges are plural, as some ideas and discourses become dominant and powerful, while others are subjugated and relinquished to the margins. As Miranda Fricker suggests, more attention should be devoted to the ways in which power functions socially to control which knowledges are important and which become marginalised as practices of epistemic injustice, which is the main 
focus of our study. Elaborating on Foucault's notions of distributed power, she argues that in questioning "wherever power is at work, we should be ready to ask who or what is controlling whom, and why" (Fricker 2007, p. 14). Fricker demonstrates how an examination of such injustices exposes the wrongs perpetuated by social power that operates as

a practically, socially situated capacity to control others' actions, where this capacity may be exercised (actively or passively) by particular social agents, or alternatively, it may operate purely structurally (ibid., p. 13).

Second, Grek (2020) calls for an interrogation that goes beyond considering IOs' influence as solitary actors, suggesting that more attention needs to be given to the interplay between them. Additionally, IOs have been recognised as playing "a significant role in the global flow of new ideas and institutional imperatives for higher education" (Shahjahan 2012, p. 216). While IOs represent more than their individual contributions to policy, they are, as Riyad Shahjahan points out, "complex hubs of policy communities" (ibid., p. 216). They mediate the assemblages of nation states and global organisations in relation to domestic and foreign policies.

To understand how IOs operate logics of knowledge control in the rapid responses to COVID-19, we need to recognise that their influence is not exercised through legislative means, but through the soft forms of power that influence normative and cognitive governance (Woodward 2009), the types of social power that control governance responses at the state and more local levels. Importantly, the tracing of the subjugation of alternative knowledges is key to understanding the knowledge/ power dynamic which produces dominant totalising knowledges (what Foucault [1980] called "global knowledges"), those that "survive and rise above the others" (Madigan 1992), compared to local knowledges as alternative knowledges that "are silenced through their disqualification" (ibid., p. 269).

Foucault's (1980) concept of local knowledges as being invoked in particular cultural relevance but simultaneously denied legitimacy to be more fully performed is useful in considering the global totalising dominance of transnational ideals over local knowledges of education practice. As Grek reminds us, the interplay across IO responses helps to understand the totalising effect.

In the next section of this article, we describe how we applied Bacchi's policy analysis approach to examine the World Bank, OECD and UNESCO policy responses to the COVID-19 pandemic. In the subsequent discussion, we take up Grek's call to consider the effects of the interplay across the three responses.

\section{Poststructural policy analysis: identifying governing knowledges}

Carol Bacchi called her approach to poststructural policy analysis "What's the problem represented to be?" (henceforth referred to as WPR). It is a critical approach to discourse analysis designed to interrogate how governing takes place (Bacchi and Goodwin 2016). The analysis emphasises making policy visible, reexamining how policy and its "things" are "constituted, or brought into being" 
(ibid., p. 4). Influenced by Foucault's work, this poststructural perspective is concerned with the rules and regulations that order our lives, with

[a]attention ... directed to the heterogenous practices, in particular the knowledge practices, that produce hierarchical and inegalitarian forms of rule (Bacchi and Goodwin 2016, p. 3).

The knowledges that undergird policies are called into question in order to understand their constructed and contingent nature and to make visible their effects on how governing takes place, including the effects on subjects, objects, places and even the kinds of problems that emerge as important for policymakers. Inherent in this approach, then, is an understanding of policy that encapsulates more than conventional legislated institutions and spaces, but also includes broader societal movements across "numerous sites, agencies and 'ways of knowing' that interrelate in important ways to shape social rules" (ibid., p. 5). Consequently, drawing on Foucauldian notions of governmentality, policy refers to "how order is maintained through politics, understood as the heterogeneous strategic relations that shape lives and worlds" (ibid., p. 6). Bacchi's WPR is guided by a series of six questions that enable analysis of how "problems" are constituted through policies. Her approach involves working backwards from the solutions presented in policies, with texts being

"levers" to open up reflection on the forms of governing, and associated effects, instituting through a particular way of constituting a "problem" (Bacchi and Goodwin 2016, p. 18).

In this way, the emphasis is on the solutions presented in policies as

the effects of policy proposals and the representations they necessarily contain (Bacchi 1999, p. 13).

Policy here is viewed as the responses from each of these three organisations as they aim to provide order and shape to the ways in which education actors engage in COVID-19 reforms but also the means by which these engagements create effects in institutions, including how education itself is constituted through the technologies of engagement. The focus is not on the intentions of particular responses but rather on how these actors govern through their articulated responses to constitute knowledge practices that guide what is valued in addressing issues arising from pandemic influences. The focus of our analysis was on the shift to remote and online learning amongst pandemic responses. Our use of WPR provides a look into the complexity of IOs and local school systems where policy harmonisation is not seen as a direct linear process but as one of "assemblages of apparatuses, processes and practices that make governing happen" (Clarke and Ozga 2011, quoted in Grek 2020, p. 313).

We analysed three policy responses to the COVID-19 crisis, two of which were "packaged" in more than one text: 
(1) the World Bank's Guidance Note on Education Systems' Response to COVID19; (World Bank 2020a) and its companion Guidance Note: Remote Learning \& COVID-19 (World Bank 2020b);

(2) the OECD's A Framework to Guide an Education Response to the COVID-19 Pandemic of 2020 (OECD 2020); and

(3) UNESCO's Global Education Coalition (UNESCO 2020a) and its related hashtag \#LearningNeverStops.

In our analysis, we drew on four of Bacchi's six WPR questions to conduct our analysis. Our focus is not on the intentions behind particular responses, but rather on how these actors govern to constitute knowledge practices that guide what is valued in addressing issues arising from the pandemic.

Initially, we examined the first two WPR questions: what the problem is represented to be in each response from the trifecta of global institutions, as a means for exploring which assumptions underlie these problem representations within policy responses from the World Bank, the OECD and UNESCO. Here we looked at the policy position documents with a view to understanding the kind of approach being advocated and how that constituted the problem of COVID-19 in each case. Drawing attention to the key concepts and binaries used within policy texts helps to appreciate the technologies of saving invoked in each policy response, locating the education programmes, activities and actors within knowledge practices in educational reform.

Additionally, in relation to these problem representations, and based on Bacchi's fifth WPR question, we examined what are the discursive, subjectification and lived effects of these problem representations on educational spaces. The focus in the analysis is not to examine the ways in which policy actors make policy, but rather on "the way policy makes people" (Bacchi and Goodwin 2016, p. 8).

Finally, in the discussion section, we present what we found when considering each of the IO responses through the lens of Bacchi's fourth WPR question, which concerns what is left unproblematic or silenced in these representations, noting what might be conceptualised differently. The shape given to problems is made visible here by noting how other knowledges are subjugated and relegated to the margins of the reality in which policies are practised. This Foucauldian influence in Bacchi's WPR seeks to demonstrate how some knowledge practices are valued while others remain invisible, and to bring forth into practice the possibilities for how we might "think otherwise" (Bacchi 2020, p. 22).

\section{The World Bank's COVID-19 pandemic response}

Adhering to neoliberal rationales, the World Bank's education policy regime has, over the past decades, produced a market model of education provision which has harmonised schooling in much of the world. Through the governing technologies of loans and structural adjustment agreements, the World Bank, along with collaborative IOs, led a global education transformation beginning in 1990. Called "Education for All", it aimed to bring education to "every citizen in every society" (World 
Bank 2014). Here, the World Bank led a particular knowledge mobilisation that promoted market and business framing of educational problems (see Mundy 2007; Shahjahan 2012).

Other IOs followed with their own contributions to a harmonisation of this message. Data produced and disseminated spoke of a critical urgency in formalising and standardising education around the world, amounting to a declaration that a global standard for education would save education in order to save nations' economies. Employing various technologies linking education, skilled and nimble human capital, and the urgency of saving economies, the World Bank produced waves of knowledge dissemination, disciplining ministries of education into reforming national and local education systems and the provision of schooling. Over the past three decades, the World Bank has become very embedded in country-level ministries of education, in some cases with direct representation, while, in others, acting as a powerful backstory and with a policy knowledge legitimising role.

The World Bank response to the COVID-19 pandemic, the focus in this study, demonstrates how the key concept of learning poverty ${ }^{3}$ is stated as the problem to which globally located solutions can provide support for locally situated problems through the World Bank's framework for action. Both the Guidance Note on Education Systems' Response to COVID-19 (World Bank 2020a); and Guidance Note: Remote Learning \& COVID-19 (World Bank 2020b), are technical directives. Their purpose is to guide ministries of education towards a prompt recovery in order to avoid what the World Bank describes as a "learning crisis leading to higher levels of learning poverty" (World Bank 2020b, p. 1, italics added). The logic of these Guidance Notes is that by missing out on schooling, students not only experience a loss of economic capital, they become a loss of economic capital. Students are viewed here as human capital subjects for the national and global economic system and, therefore, their immediate return to a functioning formal education system is the only way to ensure the future of the global economy. This line of thought is reflected, for example, in the following statement:

[E]xtended interrupted education that disengage [sic] students from the learning process has the potential cost of reversing gains in learning results (World Bank 2020a, p. 1).

The world is described here as dealing not with education in an emergency with its wide impacts on individuals, communities and nations, but with an emergency in the education of human capital.

Such one-dimensional, marketising responses from the World Bank are not unexpected. This IO is, after all, a bank, and acts on behalf of the global financial system and its wealthy advisors. However, given the World Bank's already established relationship with indebted nations as their source of education policy knowledge expertise, these two Guidance Notes carry an expectation of implementation. They are presented as a plan to follow in getting schooling back

\footnotetext{
3 According to the World Bank's own definition, "Learning poverty means being unable to read and understand a simple text by age 10" (World Bank 2019).
} 
to normal, of saving education and the future of the economy. The two documents act in unison with a definition of the problem, and with the recommended response, online schooling, intertwined in both, as we demonstrate below.

The key solution presented in the World Bank's policies to achieve equity is to add more digital technology, achievable through partnerships with private actors, so that education moves from the realm of public capital to becoming an object for private actors' gain.

[P]olicymakers should consult outside stakeholders (e.g. ICT ministries, broadcast regulators/companies, EdTech startups), ensuring the rapid development and scale-up of the designated remote learning modality (World Bank 2020b, p. 1).

In the World Bank response, the risks to the health of the market are the problem, and so, the only solution that makes sense is market-based: the market saves the market. In this problematisation, the Guidance Notes are clear directives for ministries of education. The offer of World Bank implementation assistance makes even more clear the parameters for what counts as legitimate policy knowledge in developing country-level responses.

The concept of equity is co-opted in the two World Bank COVID-19 Guidance Notes to describe children's lack of access.

This is at the core of the World Bank's approach in responding to COVID19, which aims to ensure all children and youth have access to a quality education. To achieve this end, education systems must confront issues of inequity front and center (World Bank 2020b, p. 1).

Here, the notion of equity needs to be more closely examined; not all attempts to increase equity are based on a shared understanding of what increased equity might describe. Merriam-Webster's online dictionary provides two definitions of equity that are important to this analysis. First, equity as "justice according to natural law or rights" (Merriam-Webster, n.d.) and second, "the money value of a property or of an interest in a property; the common stock of a corporation or a risk interest or ownership right in property" (ibid.). Within the World Bank's policy regime, a student educated in the formal global education system is only an asset by becoming an asset through this training. That is, equity is advanced when the student subject becomes a constant economic actor; homo economicus is the only rational subject position for students (see Brown 2015). The education system becomes an investment in the economy and the student the object for increasing the equity (i.e. money value) of the nation.

This process of objectification is in contrast to positioning students as rights bearers based on a more holistic idea of equity that includes social, economic, political and environmental justice. In the World Bank's Guidance Notes, equity exists to ensure access to market principles from which educational practices cannot be separated. The question is: what kind of equity is being saved here? While the Guidance Notes provide a range of helpful suggestions on the pragmatics of understanding the immediate impacts of COVID-19 and school closures 
on education, our study looks more closely at what the problem is that is being addressed by the policy. In our view, the stated "challenge" is that

Extended school closures may cause not only loss of learning in the shortterm, but also further loss in human capital and diminished economic opportunities (World Bank 2020b, p. 1).

If previous World Bank policy principles were aimed at ensuring that neoliberal policy regimes prevail, with educational reform striving to save nation state economies, then these Guidance Notes, drafted in the face of the COVID-19 pandemic, ensure that the World Bank's "business as usual" prevails - including the protection of the return on investment in human capital/students.

\section{The OECD's COVID-19 pandemic response}

From its position as a global education problem-solver, "a key governing logic of our age" (Bacchi 2020, p. 84), the OECD formulated its response to the pandemic as a checklist for reform. Andreas Schleicher, director of the OECD's Directorate of Education and Skills, and Fernando Reimers, of the Global Education Innovation Initiative at the Harvard Graduate School of Education, launched the OECD's 40-page policy guide, A Framework to Guide an Education Response to the COVID19 Pandemic of 2020 (OECD 2020), at the end of March 2020 and distributed it online to governments and public, private and non-profit education stakeholders. Data to inform the Framework were collected from a survey structured as a "rapid assessment" of education needs among 98 countries. Additionally, the Framework integrates an analysis of the most recent PISA data to inform "a checklist to guide the development of an education strategy during the Pandemic" (OECD 2020, p. 4).

Bacchi's (2020) study showed how the OECD has played a key role in producing a dominating technocratic problem-solving model of education while, at the same time, producing "passive and divided subjects" (ibid., p. 98) without agency, rather than citizens actively engaged in education-related decisions and programme development. Our own analysis showcases that the solutions offered by the OECD articulate a similar technocratic solution, exemplifying what Tania Li (2007) indicates is a process of rendering a problem technical within policy. That is, the technical approach of providing a checklist for change frames policy problems and solutions geared towards technical fixes that limit attention to the root causes of the problems in which education is currently situated. The Framework, as a series of items in a checklist of actionable strategies, aims at providing manoeuvres to be used by "national, state or local education authorities or by leaders of education networks" (OECD 2020, p. 4). The solution of a checklist suggests a technical set of knowledges that fit within the rationalised, knowable problem of education during the pandemic. The Framework is based on data from a 10-day survey which was sent to

networks of educators and influencers, those in the networks of the OECD and of the Global Education Innovation Initiative at the Harvard Graduate School of Education, with assistance from colleagues in several education organizations (ibid., p. 4). 
The survey focused on educational responses during the crisis of the pandemic, as captured during a short period between 18 and 27 March 2020.

In our analysis, we considered how the Framework represented the problem of education during the pandemic. We found that the key concept of autonomy was used in the Framework as a major means by which to articulate a tenuous relation between the collaborative and independent learner and a set of divided practices affecting both students and teachers. As a checklist, the recommendations suggest that students should be guided to develop the independence of self-directed learning where direct learning from a teacher is not possible. Teachers are cast in the binary role of the collaborative professional and the autonomous individual - a necessary positioning in the shift to make online and other modalities of delivery possible. The "silver lining" of the educational response to COVID-19 offered in the Framework is the capacity to develop students' learning autonomy and teachers' professional autonomy, while at the same time bolstering public-private partnerships. The divided autonomous subject here, then, is one that navigates personal learning within the space of private resource platforms based on partnerships.

Partnership was another key concept invoked in the Framework, but, in nearly all instances in which the term is used, such partnerships are constituted as relationships between education and the private sector, constituting the problem as one of needing private resources to solve the global crises of the pandemic. This is a form of dividing practice, in which the division between private and public actors renders the public ones less useful, if not nearly invisible, in pandemic conditions. For example, in identifying the means of educational delivery, the recommendation is to

explore partnerships with the private sector and the community in securing the resources to provide those devices and connectivity (OECD 2020, p. 4).

Online learning continues to be a focus throughout the Framework:

The period of distancing is an opportunity to provide online learning opportunities for job skill development. Governments should explore partnerships with the private sector to extend the availability of those opportunities through online or similar modalities during the exigency (ibid., p. 9).

Even where community actors are mentioned, they sit with assemblages of partnerships involving private actors. For example, where online education is not feasible, "partnerships with community organizations and the private sector" (ibid., p. 5; italics added) to explore alternate means of delivery are encouraged.

Finally, PISA data - supporting knowledges for engaging private sector edutech businesses - emerge in this Framework as a set of standardised yet perpetual truths, rendered visible by a "governing by numbers" (Grek 2009). The persistent need to validate the comparative data collected through the PISA survey (the Framework refers to the latest round conducted in 2018 [OECD 2019]) sets up comparator criteria for measuring what works in education. Yet, in the Framework, we see a secondary set of survey data on which the checklist items are 
based, collected with expedient measures to capture global responses to the pandemic. Thus, the immediacy of the pandemic crisis is tempered with the "longheld" truths of PISA concerning the incapabilities of education systems to handle edu-tech and the inability of the teaching profession to deliver the education needed in such crises.

The checklist draws on data from PISA and the survey as technologies of "governance by numbers" to represent the problem as rational, technical and, consequently, conquerable through a rationalised checklist for action. The checklist calls on educators, governments and ministries of education to be guided by it, and to embrace private-sector partnerships in the technocratic problem-solving model of education (Bacchi 2020). In this way, the Framework - as a technology of saving - constitutes the problems of the pandemic as technical ones, in which the pervading logic is that edu-tech is a logical and necessary partner.

\section{UNESCO's COVID-19 pandemic response}

UNESCO's response to the global pandemic school closures emerged as a somewhat unique approach, in that it is two-pronged. Unlike the World Bank guidelines and the OECD checklist, UNESCO communicated its response to the global COVID-19 pandemic in a webpage, launching the Global Education Coalition (UNESCO 2020a) and the related hashtag \#LearningNeverStops on 25 March 2020. While UNESCO has played a role in decades of curriculum development designed for local teachers and students, providing a quite diverse range of ideas and supporting knowledge holders from around the world, the new Coalition specifically targets a unified and urgent move to online education provision. The Coalition aims to support online learning with "equitable solutions and access" (ibid.) and to enable coordinated, networked responses. In her video message to launch the Coalition and \#LearningNeverStops, UNESCO Director-General Audrey Azoulay described the current time of crisis as a "radically new age of learning" (Azoulay 2020, 0:14) where "schooling on our planet has gone virtual" (ibid., 0:17). She continued with a call for "innovation, partnership and solidarity" (ibid., 0:36) to address the urgency, and ended her message with the idea that what we were witnessing was the transformation of education and that the work done now to save schooling constituted the knowledge needed "for the future of education" (ibid., 1:28).

The hashtag \#LearningNeverStops travelled through the UNESCO network, spreading the message and the call for saving schooling through online provision. This strategy of crowdsourcing answers to the implementation of online schooling which enlisted people across sectors, letting them know about the newly formed Coalition made up of members of "the UN family, civil society, IT partners and media companies" (Azoulay 2020, 0:56). The list of members includes influential large international non-governmental organisations (INGOs) along with some of the world's key regional development banks, including the World Bank. Among the information technology and media companies are some of the world's largest corporations, including Microsoft, Google, Facebook, Weidong, Coursera, Zoom, 
Moodle, Huawei and IBM, to name a few. To prospective members, UNESCO offers the following invitation:

Interested organization [sic] should clearly specify what free support, tools or services they can offer countries that might help them extend educational opportunities during periods of school closure. Emphasis is placed on "free". The coalition seeks to broker solutions with country needs and, in the current emergency context, all solutions listed on the coalition platform should be available free of charge (UNESCO 2020a).

At the time of this study, the corporate partners were included in a list and linked as providing solutions (UNESCO 2020b). There is no indication of other partnerships or negotiations made as a result of this list, and a search of such agreements was beyond the scope of this study. However, despite a caveat published on the webpage, describing participation by corporate entities as being "free of charge", it seems obvious, given the massive interest in a quick move to online learning, that a lucrative market for online education, now boosted by "members of the UN family" and other global agencies, was opening before them. Such relationships are the foundation of most public-private partnerships, with the intention that the relationship will lead to economic gain (see Robertson 2012).

In UNESCO's Coalition building for the task of "designing and deploying solutions" (Azoulay 2020, 1:08), it is key to look at how this approach works to position education as an object of mobility as it moves out into UNESCO's global network. The objectification of education through a hashtag renders education as mobile, networked and diffused, across a coalition of actors and into the extensive reach of social media. Supposing the future of schooling is indeed online, the private sector actors stand ready to bring that to fruition. In addition to individual corporation benefits, the private sector as a whole is positioned on the UNESCO website as being on standby, ready to provide what is needed for worldwide education. Edu- business is positioned as the ultimate saving subject, ready to deliver an objectified online education. These private actors are featured alongside large civil society organisations and development banks, blurring the distinction between public and private sectors to send a clear message to policymakers and educational workers, affirming a shifting policy and institutional context towards global private-sector-friendly schools, curricula and policies.

Within the Global Education Coalition platform, UNESCO also hosts detailed stories of individual schools and experiences of education during the pandemic from many parts of the world, alongside short videos of corporate and INGO executives' statements of what they bring to the task. A collection of "good stories", including some cautionary tales, is hosted on the website. As students and their learning become increasingly described as static objects in need of saving, the twopronged approach reveals its workings. UNESCO brings powerful global information technology and virtual education actors into the centre of their policy network. Yet, teachers, students and local school trustees are excluded. Instead, a space is created where non-central actors can share stories from the field, already defined by the IOs' pandemic response. It is a kind of truth-telling space for sharing "best practice" in education during the pandemic. While the impact of the private actors 
in the Coalition is not revealed, stories of success are gathered from teachers and students through the extension of the Coalition via hashtag and already established connections.

Fricker's (2007) ideas of epistemic injustice 4 are helpful in understanding these stories. Again, regardless of Coalition partners' intentions, which we can assume to be good and generous in their sharing, our focus here is on how education is governed through knowledge practice. While collection and publication of good stories are a nod towards, if not commitment to, epistemic trust (see Fricker 2007), it is reasonable to see local community and teacher knowledge as being made invisible beyond stories of compliance, in what Fricker describes as hermeneutical inequality -

the lived experience of being unfairly disadvantaged in rendering one's social experience intelligible, to others and even to oneself (Fricker 2008, p. 70).

Throughout the Coalition's dedicated webpage (UNESCO 2020b), discourses of delivering online schooling move between provision of digital technology and individual student learning - without concern or engagement with teachers' professional knowledge of content or pedagogy. Discourses of online delivery privilege knowledges of technology provision in partnerships, rather than professional knowledges within teachers' practices. Also missing are voices from informal and non-formal educators working for integration within communities and issues. The erasure of the social components of education fits snugly within the past decades of IO knowledge economy-focused, standardised education discourse.

In many ways, the duality of the two-pronged approach reflects the distinction of UNESCO's position as an IO from that of the solely economically focused World Bank and OECD. Within the multilateral world of education policy influence, UNESCO occupies a divided position. Through its national offices and programming, it serves as a gathering place for local knowledge and actors. But at the same time it serves as a global education policy actor, influencing national and local education provision in harmony with other IOs. With these global actors actively promoting a simultaneous increase in investments in education and fluid involvement of private-sector actors in public concerns (Gorur 2020), the divided position of UNESCO requires creative contortionism. It needs to uphold a protective voice for democracy and the rights of children, retaining its role as champion of holistic approaches to education that are linked to urgent planetary issues. At the same time, welcoming private-sector actors who would benefit greatly from marketising schooling puts at risk the achievement of the social and environmental goals of education.

As Christopher Lubienski (2016) points out, the privatisation agenda is not a straightforward one, with the main goal of global education policy actors not

\footnotetext{
${ }^{4}$ Fricker explains epistemic injustice more generally as being "a wrong done to someone specifically in their capacity as a knower" (Fricker 2007, p. 1). But she distinguishes between its two forms, testimonial injustice and hermeneutical injustice: "Testimonial injustice occurs when prejudice causes a hearer to give a deflated level of credibility to a speaker's word; hermeneutical injustice occurs at a prior stage, when a gap in collective interpretive resources puts someone at an unfair disadvantage when it comes to making sense of their social experiences" (ibid.).
} 
necessarily targeting the privatisation of all schools. Rather, it ensures that education policy supports ongoing market solutions through their normalisation as accepted national and institutional education policy knowledge. In this divided response, UNESCO's representation of the problem of providing education during the pandemic reflects the duality of this IO's position, epitomising what Walter Mignolo (2011) describes as the basic paradoxical problem of "Western modernity" (ibid.). The "shine" or benefit of modernity's progress hides its shadow, that of a dependence on sustained human poverty and the destruction of nature to feed its growth through the pathways established through centuries of global European colonialism.

\section{The interplay of 10 responses}

The focus of our concern in this article is not to compare IOs' individual responses, but rather to consider the interplay of their influence (Grek 2020). The WPR approach we used for our analysis directs attention to strategic relations as "societal relations and practices rather than intentional manipulation" (Bacchi and Goodwin 2016 , p. 112). That is, the interplay of influence that has our attention in this analysis is not one of intentional strategic decision-making (although that might exist), but rather how the problem of education has come to be tentatively and contingently constructed within the mass of responses. The point of such politics, as Bacchi and Goodwin outline, is to draw on Foucault's notions of emancipation, whereby we aim to open up the possibilities to minimise dominating perspectives of problems, "creating the possibility of thinking otherwise" (Bacchi and Goodwin 2016, p. 108). Accordingly, in this section, we consider two further aspects in thinking holistically about the interplay of responses: the urgency of problems that come to the fore and what is left out in such representations.

We turn first to the urgency of the problem representations that have emerged. As the world went suddenly into lockdown, sending individuals to their homes and shutting businesses and institutions, school closures presented considerable problems in practical terms. While many people lamented the loss of childcare as they set up makeshift worksites at home, others wondered what impact school closures would have on children's learning trajectories in the longer term. Yet, in our analysis, the interplay of responses across the three IOs should not be taken as naturalised, logical solutions to the problem of education during the pandemic.

The World Bank, OECD, and UNESCO, key global education actors, hold the gaze of policymakers around the world concerned with educational reform. The influence of their responses has to be located within the subject position they have performed within educational policy spaces. These actors are situated in a privileged position, endowed with policy influence, particularly in the development of human capital linked to nation-state economic policies and agendas over the past 30 years. The OECD pioneered compiling comparative data on education performance dating back to the 1960s (Grek 2020), including the establishment of indicators followed by a partnership which provided comparative data across OECD member countries. The launch and uptake of the OECD's Programme for International Student 
Assessment (PISA) in 2000 has enabled the OECD to occupy a position of power, providing a tool of governance by comparison on a grand scale (Gorur 2020; Martens 2007).

Within the two decades between 1980 and 2000, a decrease in North-South flows of government aid to education led to a power shift from UNESCO to the World Bank (Mundy 2007). The World Bank's involvement in education has long been aimed at integration and coordination of education policies at the national level, coordination across governance levels and subjectification of the government as enabler by "creat[ing] choices, provid[ing] information and incentives, facilitat[ing] cooperation and provision" (World Bank 2003, p. 59). Enabling the provision of private-sector delivery in education has been a key policy strategy of the World Bank (Jakobi 2007), paving the way for marketisation and privatisation advancement in education policy, and supporting the efficiency and effectiveness of non-governmental actors in providing education (World Bank 1999).

The trifecta of IO responses to COVID-19 is manifested through technologies that aim to save education in varied ways: a virtual coalition network objectified and mobilised by a hashtag (UNESCO); a checklist of items as technical responses and a framework for action (OECD); and two sets of guidelines to mitigate learning poverty (World Bank). Yet, among these dispersed responses, we found a shared immediate urgent call for online education to save education, in that the problem representation created the urgency for systematic responses involving remote and online learning which operate here as technologies of saving. Without schools, there would be no education, they said. Children without schools presented risks to their own and the world's future. The power of this knowledge to discursively render children as objects in their communities, constructing them as assets to be managed against checklists, guidelines and hashtags, is concerning. Being saved by digital technology provided by Google, Microsoft, Zoom and other giant global corporations overshadows the role that families and communities play in the education of children.

The second point we want to draw attention to in our consideration of the interplay of IO responses is what is missing in this problem representation. What alternatives might be present in local contexts for children to learn? Such a dynamic closure of schools might well have provided children with new insights into their communities and the work of family members, extended in the many ways they are in different communities and cultures. The disqualification of informal and non-formal education in such an emergency disqualifies children and youth from seeing themselves within the community and seeing their role as co-creators of an emergency response. We are not arguing for children being cast aside and not protected but, rather, contending that as members of families and communities impacted by the emergency, they might be better protected by calls for local support built on ideas of sustainability, of restoration and of self-sufficiency, all core ideals already embedded in discourses around the Sustainable Development Goals and the United Nations Declaration on the Rights of Indigenous Peoples (see, for example, Borrows et al. 2019, and McCoy et al. 2016). The sole vision for education in online deliveries necessarily constitutes online education as a saving technology, but when we consider the dangers of private sector creep into education, there is a concern for what 
is rendered invisible in "saviour" discourses. What will continue to be weakened and made irrelevant when not captured by the checklist, the hashtag and the framework?

We offer that these subjugated discourses will become more fully known as the policy responses continue to emerge and produce effects in educational communities. While we are sceptical that the impact of these societal relations that emerge through enhanced partnerships with edu-business and private actors can lead to a better realisation of democratic practices in education, according the most say to those affected by educational policy, our analysis aims to help make visible where other opportunities might exist. How might we steer away from the dominance of privatised systems that create urgency for profit in education towards problematising the lack of local engagements and the need for sustainability? The problematisation of the pandemic through these responses constitutes online and digital technologyled education as necessary, but its dominance as we move away from the urgency of the pandemic is a bias worth watching. We know the social conditions in which this response "made sense", but what conditions must be maintained and privileged, through our choice of partnership, that will make the continued saving of education through digital technology sensible and necessary? Our study suggests that local policymakers, including community-based and national actors, must be invited into the discussion to envision other possibilities, in the knowledge that emancipation in policy responses is possible.

\section{Conclusion}

The initial review of IO involvement we offer here in this brief analysis is limited by time, by rapidly changing network spaces and by uncertainty about the boundaries of the crisis. While our analysis is steeped in a critical approach, we also acknowledge the difficulty of coming up with education responses to crises such as the current pandemic, given the dispersed implications across economy, society and institutions. Yet, Fricker's (2007) admonition about the necessity of being alert to injustice is a key aspect in how we might advance educational policy responses amid the crisis of the pandemic. Returning to Fricker's concern for examining power by asking who or what is controlling whom and why, we posit that one of the glaring silences is the role of education in supporting democracy, particularly in conditions of crisis. The Foucauldian notion of social power is not ignorant to the kinds of ways in which the three responses covered in this analysis engage both structural force and individual agency for education actors. Yet, testimonial injustice (Fricker 2007) occurs when a speaker is deemed irrelevant and not credible, because of the bias of the hearer. What forms of education could emerge if IOs centred democracy, sustainability, human rights and children's capacity as knowledge holders as key to crisis responses? When testimonies of saving are centred on privatised, corporate edu-tech aimed at online education delivery, there are significant risks for the epistemological erasure of other crises we are currently finding ourselves in. 
Acknowledgement Following advice from Springer to share COVID-19-related research as early as possible, a draft version of this article was posted on Western University's recognised preprint server, Scholarship@Western.

\section{References}

Azoulay, A. (2020). Global Education Coalition launch message [video recording, 25 March]. Paris: UNESCO. Retrieved 21 May 2020 from https://bangkok.unesco.org/content/global-educationcoalition-message-audrey-azoulay-unesco-director-general.

Bacchi, C. (1999). Women, policy and politics: The construction of policy problems. London: SAGE.

Bacchi, C. (2009). Analysing policy: What's the problem represented to be? Frenchs Forest: Pearson Australia

Bacchi, C. (2020). Problem-solving as a governing knowledge: "Skills"- testing in PISA and PIAAC. Open Journal of Political Science, 10(1), 82-105. https://doi.org/10.4236/ojps.2020.101007.

Bacchi, C., \& Goodwin, S. (2016). Poststructural policy analysis: A guide to practice. New York: Palgrave Macmillan.

Ball, S.J. (2012). Global Education Inc.: New policy networks and the neoliberal imaginary. London: Routledge.

Bonal, X., \& Rambla, X. (2003). Captured by the totally pedagogised society: Teachers and teaching in the knowledge economy. Globalization, Societies, and Education, 1(2), 169-184. https://doi. org/10.1080/14767720303916.

Borrows, J., Chartrand, L., Fitzgerald, O., \& Schwartz, R. (Eds) (2019). Braiding legal orders: Implementing the United Nations Declaration on the Rights of Indigenous Peoples. Waterloo, ON: Centre for International Governance Innovation (CIGI).

Brown, W. (2015). Undoing the demos: Neoliberalism's stealth revolution. Brooklyn, NY: Zone.

Clarke, J., \& Ozga, J. (2011). Governing by inspection? Comparing school inspection in Scotland and England. Paper presented at the Social Policy Association conference, University of Lincoln, 4-6 July 2011.

El-Taliawi, O. G., \& Hartley, K. (2020). The COVID-19 crisis and complexity: A soft systems approach. Contingencies and Crisis Management, 00, 1-4. https://doi.org/10.1111/1468-5973. 12337.

Foucault, M. (1980). Power/knowledge: Selected interviews and writings. New York: Pantheon.

Foucault, M (2008 [1979]). The birth of biopolitics: Lectures at the Collège de France, 1978-1979. London: Palgrave Macmillan.

Foucault, M. (2009 [1978]). Security, territory, population: Lectures at the College de France, 1977-78. Ed. by A.I. Davidson; transl. by G. Burchell. London: Palgrave Macmillan.

Fricker, M. (2007). Epistemic injustice: Power and the ethics of knowing. Oxford: Oxford University Press.

Fricker, M. (2008). Forum on Miranda Fricker's Epistemic injustice: Power and the ethics of knowing: Précis. Theoria: An International Journal for Theory, History and Foundations of Science, 23(1), 69-71. http://www.jstor.org/stable/23923916.

Gorur, R. (2020). Embracing numbers? International Studies in Sociology of Education, 29(1-2), 187197. https://doi.org/10.1080/09620214.2020.1720518.

Greer, T.H. (1968). Ben Tre's destruction. New York Times, 20 February, p. 46.

Grek, S. (2009). Governing by numbers: The PISA "effect" in Europe. Journal of Education Policy, 24(1), 23-37. https://doi.org/10.1080/02680930802412669.

Grek, S. (2020). Interdependency in transnational education governance. In G. Fan \& T. Popkewitz (Eds), Handbook of education policy studies (pp. 209-238). Singapore: Springer. https://doi.org/10.1007/ 978-981-13-8347-2_14.

Jakobi, A. P. (2007). Converging agenda in educational policy: Lifelong learning in the World Bank and International Labour Organization. In K. Martens, A. Rusconi, \& K. Leuze (Eds.), New arenas of education governance: The impact of international organizations and markets on educational policymaking (pp. 95-113). New York: Palgrave Macmillan.

Li, T. (2007). The will to improve. Durham: Duke University Press. 
Lind, M. (1999). The necessary war: A Reinterpretation of America's most disastrous military conflict. New York, NY: The Free Press.

Lubienski, C. (2016). Sector distinctions and the privatization of education policymaking. Theory and Research in Education, 14(2), 193-212. https://doi.org/10.1177/1477878516635332.

Madigan, S. P. (1992). The application of Michel Foucault's philosophy in the problem of externalizing discourse of Michael White. Journal of Family Therapy, 14(3), 265-279. https://doi.org/10.1046/j. 1992.00458.x.

Martens, K. (2007). How to become an influential actor: The "comparative turn" in OECD education policy. In K. Martens, A. Rusconi, \& K. Leuze (Eds.), New arenas of education governance: The impact of international organizations and markets on educational policymaking (pp. 40-56). New York: Palgrave Macmillan.

McCoy, K., Tuck, E., \& McKenzie, M. (2016). Land education: Rethinking pedagogies of place from Indigenous, postcolonial, and decolonizing perspectives. London/New York: Routledge.

Merriam-Webster (n.d.). Equity. In Merriam-Webster dictionary [online resource]. Springfield, MA: Merriam-Webster. Retrieved 21 May 2020 from https://www.merriam-webster.com/dictionary/ equity.

Mignolo, W. D. (2011). The darker side of Western modernity: Global futures, decolonial options. Durham, NC: Duke University Press.

Mundy, K. (2007). Education multilateralism: Origins and indications for global governance. In K. Martens, A. Rusconi, \& K. Leuze (Eds.), New arenas of education governance: The impact of international organizations and markets on educational policymaking (pp. 19-39). New York: Palgrave Macmillan.

OECD (Organisation for Economic Co-operation and Development) (2019). PISA 2018 database [online resource]. Paris: OECD. Retrieved 29 January 2021 from https://www.oecd.org/pisa/ data/2018database/).

OECD (2020). A framework to guide an education response to the COVID-19 pandemic of 2020. Paris: OECD. Retrieved 1 June 2020 from https:/globaled.gse.harvard.edu/files/geii/files/framework_ guide_v2.pdf

Robertson, S. (2012). Placing teachers in global governance agendas. Comparative Education Review, 56(4), 584-605. https://doi.org/10.1086/667414.

Shahjahan, R. A. (2012). The roles of international organizations (IOs) in globalizing higher education policy. In J. Smart \& M. Paulsen (Eds.), Higher education: Handbook of theory and research (pp. 369-407). Dordrecht: Springer.

UN (United Nations) (2007). United Nations declaration of the rights of Indigenous people. UN General Assembly Resolution A/RES/61/295. New York. UN. Retrieved 25 January 2021 from https:// undocs.org/A/RES/61/295.

UN (2020 [2015]). The 17 goals [dedicated webpage]. New York. UN, Department of Economic and Social Affairs. Retrieved 25 January 2021 from https://sdgs.un.org/goals.

UNESCO (United Nations Educational, Scientific and Cultural Organization) (2020a). Global Education Coalition [dedicated Global Education Coalition webpage]. Paris: UNESCO. Retrieved 21 May 2020 from https://en.unesco.org/covid19/educationresponse/globalcoalition

UNESCO (2020b). Distance learning solutions [dedicated Global Education Coalition webpage]. Paris: UNESCO. Retrieved 21 May 2020 from https://en.unesco.org/covid19/educationresponse/solutions

WHO (World Health Organization) (2020). Director-General's opening remarks at the media briefing on COVID-19 - 11 March 2020. WHO, 11 March [webnews]. Geneva: World Health Organization. Retrieved 25 January 2021 fromhttps:/www.who.int/director-general/speeches/detail/who-directorgeneral-s-opening-remarks-at-the-media-briefing-on-covid-19-11-march-2020.

Williamson, B. (2020). New pandemic edtech powers. Code Acts In Education, 1 April [blog post]. Retrieved 21 May 2020 from https://codeactsineducation.wordpress.com/2020/04/01/new-pande mic-edtech-power-networks.

Woodward, R. (2009). The Organisation for Economic Co-operation and Development. London: Routledge.

World Bank (1999). Education sector strategy. Washington, DC: World Bank. Retrieved 3 March 2021 from http://documents1.worldbank.org/curated/en/406991468178765170/pdf/196310REPLACEM0 cation0strategy01999.pdf.

World Bank (2003). Lifelong learning and the knowledge economy. Challenges for developing countries. Washington, DC: World Bank. Retrieved 3 March 2021 from http://documents1.worldbank.org/ 
curated/en/528131468749957131/pdf/Lifelong-learning-in-the-global-knowledge-economy-chall enges-for-developing-countries.pdf.

World Bank (2014). Education for all [online brief]. World Bank website, Understanding poverty section, 4 August. Retrieved 30 January 2021 from https://www.worldbank.org/en/topic/education/brief/ education-for-all.

World Bank (2019). Learning poverty. World Bank Brief, 15 October [online brief]. Washington, DC: The World Bank. Retrieved 26 January 2021 from https://www.worldbank.org/en/topic/education/ brief/learning-poverty.

World Bank (2020a). Guidance note on Education systems' response to COVID 19 [published 25 March]. Washington, DC: The World Bank. Retrieved 15 May 2020 from http://documents1.worldbank.org/ curated/en/450881585235950757/Guidance-Note-on-Education-Systems-Response-to-COVID19. pdf.

World Bank (2020b). Guidance note: Remote learning \& COVID-19 [updated 7 April]. The World Bank Education Global Practice series. Washington, DC: The World Bank. Retrieved 15 May 2020 from http://documents. worldbank.org/curated/en/531681585957264427/pdf/Guidance-Note-on-RemoteLearning-and-COVID-19.pdf.

Publisher's Note Springer Nature remains neutral with regard to jurisdictional claims in published maps and institutional affiliations.

Lynette Shultz PhD, is a Professor and the Director of the Centre for Global Citizenship Education and Research in the Faculty of Education at the University of Alberta, Canada. Her key research is focused on democracy, social justice, global citizenship education, and the internationalisation of higher education.

Melody Viczko PhD, is an Associate Professor in the Faculty of Education at Western University, Canada. Her research is focused on policy and governance in higher education.

\section{Authors and Affiliations}

\section{Lynette Shultz ${ }^{1}$ (i) $\cdot$ Melody Viczko $^{2}$}

$\triangle$ Lynette Shultz

lshultz@ualberta.ca

Melody Viczko

mviczko@uwo.ca

1 University of Alberta, Edmonton, AB, Canada

2 Western University, London, ON, Canada 